\title{
Anticancer activity of a synthetic peptide derived from harmoniasin, an antibacterial peptide from the ladybug Harmonia axyridis
}

\author{
IN-WOO KIM ${ }^{1 *}$, JOON HA LEE ${ }^{1 *}$, YOUNG-NAM KWON $^{1}$, EUN-YOUNG YUN ${ }^{1}$, SUNG-HEE NAM $^{1}$, \\ MI-YOUNG AHN ${ }^{1}$, DONG-CHUL KANG ${ }^{2}$ and JAE SAM HWANG ${ }^{1}$ \\ ${ }^{1}$ Department of Agricultural Biology, National Academy of Agricultural Science, RDA, Suwon 441-853; \\ ${ }^{2}$ Ilsong Institute of Life Science, Hallym University, Anyang 431-060, Republic of Korea
}

Received March 28, 2013; Accepted May 13, 2013

DOI: $10.3892 /$ ijo.2013.1973

\begin{abstract}
Harmoniasin is a defensin-like antimicrobial peptide identified from the ladybug Harmonia axyridis. Among the synthetic homodimer peptide analogues derived from harmoniasin, HaA4 has been found to have antibacterial activity without hemolytic activity. In this study, we investigated whether HaA4 has anticancer activity against human leukemia cell lines such as U937 and Jurkat cells. HaA4 manifested cytotoxicity and decreased the cell viability of U937 and Jurkat cells in MTS assay and LDH release assay. We found that HaA4 induced apoptotic and necrotic cell death of the leukemia cells using flow cytometric analysis, acridine orange/ethidium bromide staining and nucleosomal fragmentation of genomic DNA. Activation of caspase-7 and -9 and fragmentation of poly (ADP-ribose) polymerase was detected in the HaA4-treated leukemia cells, suggesting induction of a caspase-dependent apoptosis pathway by HaA4. Caspase-dependent apoptosis was further confirmed by reversal of the HaA4-induced viability reduction by treatment of Z-VAD-FMK, a pan-caspase inhibitor. In conclusion, HaA4 caused necrosis and caspase-dependent apoptosis in both U937 and Jurkat leukemia cells, which suggests potential utility of HaA4 as a cancer therapeutic agent.
\end{abstract}

\section{Introduction}

Living organisms are exposed daily to microbial infections and pathogens. In order to defend themselves against such

Correspondence to: Dr Jae Sam Hwang, Department of Agricultural Biology, National Academy of Agricultural Science, RDA, 61-2th Seodun-dong, Suwon 441-853, Republic of Korea

E-mail: hwangjs@korea.kr

${ }^{*}$ Contributed equally

Key words: Harmonia axyridis, anticancer activity, necrosis, apoptosis, caspase infectious agents, they have developed potent defensive mechanism, i.e., innate and adaptive immunity. In innate immunity, antimicrobial peptides (AMPs) that possess potent antibiotic activity against bacteria, fungi and even certain viruses play important roles in the host defense mechanisms of most living organisms including plants, insects, amphibians and mammals (1-3).

Insect AMPs are cationic and amphipathic. Although insect AMPs display variable length, sequences and structures, most AMPs have relatively small $(<5 \mathrm{kDa})$ molecular masses $(4,5)$. In case of insect defensins, that was first isolated from the culture medium of an embryonic cell line of the flesh fly, Sarcophaga peregrine (6), are members of a widely distributed family of AMPs. Insect defensin contains six conserved cysteine residues engaged in three intradisulfide bonds $(4,5)$ and have antimicrobial activity against Gram-positive bacteria and fungi $(5,7)$.

Interestingly, several insect AMPs show cytotoxic effects against a broad range of cancer cell lines such as mouse myeloma, melanoma, lymphomas, leukemia, breast cancer and lung cancer (8-12). Coprisin belongs to the defensin family of insect AMPs, and has been identified from dung beetle, Copris tripartitus (13) and its analogue CopA 3 showing cytotoxicity against cancer cell lines as well as strong antibacterial activity against microbes (14-16).

Previously, we characterized the antibacterial activity of the synthetic analogue of harmoniasin, HaA4 that was identified from the ladybug, Harmonia axyridis. Active region of harmoniasin was defined and selected to be modified as a homodimeric peptide. HaA4 displayed more potent antibacterial activity than that of the native peptide (17). HaA4 might also retain cytotoxic effect on cancer cells similarly to some other AMPs. Therefore, we investigated the anticancer activity of the HaA4 peptide against two human leukemia cell types in the present study and report that the anticancer effect of HaA4 is caused by necrosis and apoptosis.

\section{Materials and methods}

Peptide synthesis. Harmoniasin is a defensin-like peptide consisting of 50 amino acid residues with three intra-disulfide 
bonds. Because of the large molecular weight and disulfide bonds, we designed a variety of analogues based on the harmoniasin sequence in a previous study (17). The resulting homodimer peptide, named $\mathrm{HaA} 4$, was synthesized and provided by Anygen Co., Ltd. (Gwangju, Korea).

Cell culture. Raw 264.7, Jurkat and U937 cells were maintained in DMEM and RPMI-1640 medium containing $10 \%$ FBS, penicillin $\mathrm{G}(100 \mathrm{U} / \mathrm{ml})$ and streptomycin $(100 \mu \mathrm{g} /$ ml) (Invitrogen, Carlsbad, CA, USA), respectively. Cells were cultured at $37^{\circ} \mathrm{C}$ in a humidified incubator with $5 \% \mathrm{CO}_{2}$.

Cell viability assay. Cells were plated into 96-well tissue culture plates $\left(2 \times 10^{4}\right.$ cells/well $)$ and treated with various concentrations $(50,100,150$ and $200 \mu \mathrm{g} / \mathrm{ml})$ of HaA 4 or without HaA4. After incubation for $24 \mathrm{~h}$, viability of the cancer cells was measured using the CellTiter 96 AQueous One Solution Cell Proliferation Assay according to the manufacturer's protocol (Promega, Madison, WI, USA). Optical density was measured at $490 \mathrm{~nm}$ with a microplate reader (Beckman DTX 8800 multi detector). Reversal of viability reduction by HaA4 was attempted by treatment with Z-VAD-FMK (Promega), a broad-spectrum caspase inhibitor at indicated concentration.

$L D H$ release assay. Cell membrane integrity was analyzed by measuring LDH activity. LDH activity was measured using a Cytotoxicity Detection kit (Roche Applied Science). In brief, the cells were seeded at $1 \times 10^{4}$ cells/well into a 96-well tissue culture plate in assay medium (RPMI-1640 containing $1 \%$ FBS). The cells were treated with different doses of HaA4. After $24 \mathrm{~h}$ of incubation, $5 \mu \mathrm{l}$ of lysis solution was added to high control samples as a positive control and the plate incubated for an additional $15 \mathrm{~min}$. Then, $100 \mu \mathrm{l}$ reaction mixture was added to each well on the 96-well plate and incubated for $15 \mathrm{~min}$. Finally, $50 \mu \mathrm{l}$ stop solution was added to each well on the plate and the absorbance at $490 \mathrm{~nm}$ was measured using a microplate reader. The percent cytotoxicity was calculated by the following equation: Cytotoxicity $(\%)=(\exp$. value - low control)/(high control - low control) x 100.

Annexin V/propidium iodide (PI) staining. Jurkat and U937 cells were plated into 6-well tissue culture plates $\left(1 \times 10^{6}\right.$ cells/ well) and treated with various concentrations (50, 100, 150 and $200 \mu \mathrm{g} / \mathrm{ml}$ ) of $\mathrm{HaA} 4$ or without $\mathrm{HaA} 4$. After incubation for $4 \mathrm{~h}$, cells were harvested and washed twice with cold PBS and once with $1 \mathrm{X}$ binding buffer (0.01 M HEPES/NaOH (pH 7.4), $0.14 \mathrm{M} \mathrm{NaCl}, 2.5 \mathrm{mM} \mathrm{CaCl} 2$ ). Cells were prepared in $100 \mu \mathrm{l}$ of the binding buffer ( $1 \times 10^{5}$ cells) and then, added with $5 \mu \mathrm{l}$ of FITC Annexin V and PI. The cells were gently mixed by vortex and incubated for $15 \mathrm{~min}$ at room temperature in the dark. After the incubation, $400 \mu 1$ of $1 \mathrm{X}$ binding buffer was added to each tube. Stained cells were measured by flow cytometry with a BD FACSCalibur cytometer (BD Biosciences) and CellQuest software (BD Biosciences) was used for analysis of the results.

Acridine orangelethidium bromide staining. Cells were seeded in 6-well tissue culture plates $\left(1 \times 10^{6}\right.$ cells/well), treated without or with $\mathrm{HaA} 4(50,100$ and $150 \mu \mathrm{g} / \mathrm{ml})$ for $24 \mathrm{~h}$ and the cells were washed with PBS. Then, the cells were stained with mixture of acridine orange $(3 \mu \mathrm{g} / \mathrm{ml})$ and ethidium bromide
Table I. Sequence of harmoniasin analogues.

\begin{tabular}{|c|c|c|c|}
\hline \multirow[b]{2}{*}{ Peptide } & \multirow[b]{2}{*}{ Amino acid sequence } & \multicolumn{2}{|c|}{ Mass (Da) } \\
\hline & & Measured & Theoretical \\
\hline HaNP & $\begin{array}{l}\text { IGGYCSELDL-NH }_{2} \\
\text { IGGYCSELDL-NH }_{2}\end{array}$ & 2134.8 & 2134.4 \\
\hline $\mathrm{HaA} 4$ & 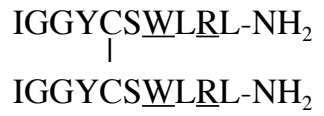 & 2330.2 & 2330.8 \\
\hline
\end{tabular}

Vertical bar represents a disulfide linkage between cysteine residues in the sequence. Substituted residues are underlined.

(10 $\mu \mathrm{g} / \mathrm{ml})$ and observed immediately using AxioImager $\mathrm{Z1}$ fluorescence microscope (Carl Zeiss, Germany).

DNA fragmentation assay. For the DNA fragmentation assay, $2 \times 10^{6}$ cells were seeded into 6 -well plates and treated with $200 \mu \mathrm{g} / \mathrm{ml} \mathrm{HaA} 4$ or without HaA4 for $24 \mathrm{~h}$. Cells were collected, washed once with PBS, lysed in a solution containing $10 \mathrm{mM}$ Tris-HCl (pH 7.4), 10 mM EDTA (pH 8.0) and $0.5 \%$ Triton $\mathrm{X}-100$ on ice for $30 \mathrm{~min}$ and then centrifuged at $15,000 \mathrm{rpm}$ for $5 \mathrm{~min}$. The supernatant was digested with $0.1 \mathrm{mg}$ of RNase $\mathrm{A} / \mathrm{ml}$ and $1 \mathrm{mg}$ of proteinase $\mathrm{K} / \mathrm{ml}$ for $1 \mathrm{~h}$ at $55^{\circ} \mathrm{C}$ in the presence of $1 \%$ sodium dodecyl sulfate (SDS). DNA was extracted from the digested supernatant with phenol and chloroform, precipitated in cold ethanol and subjected to electrophoresis on $2 \%$ agarose gels containing ethidium bromide. DNA fragments were visualized by UV light.

Terminal deoxynucleotidyl transferase-mediated dUTP nickend labeling (TUNEL assay). Jurkat and U937 cells were plated into 6 -well plates $\left(2 \times 10^{6} / \mathrm{ml}\right)$ and treated with or without HaA4 $(200 \mu \mathrm{g} / \mathrm{ml})$ for $24 \mathrm{~h}$. TUNEL assay was performed with DeadEnd $^{\mathrm{TM}}$ Fluorometric TUNEL system according to the manufacturer's instructions (Promega) to determine apoptotic cells.

Immunoblot analysis. Cells were washed with cold PBS and lysed in buffer [150 mM NaCl, $50 \mathrm{mM}$ Tris- $\mathrm{HCl}(\mathrm{pH} 8.0)$, $5 \mathrm{mM}$ EDTA and 1\% Nonidet P-40]. Equal amount of protein was separated by SDS-polyacrylamide gel electrophoresis (12\% SDS-PAGE) and transferred onto a nitrocellulose membrane. The antigen-antibody complexes were detected using FluorChem (Alpha Innotech, USA). Polyclonal antibodies against caspase-7, -9, PARP and AIF were obtained from Cell Signaling Technology (MA, USA). The $\beta$-actin antibody was purchased from Sigma-Aldrich (St. Louis, MO, USA) and the broad-spectrum caspase inhibitor, Z-VAD-FMK, was obtained from Promega.

\section{Results and Discussion}

The peptide. The primary amino acid sequence of the synthetic harmoniasin analogues are shown in Table I. HaA4 peptide was used in this study. Dimerized peptides by disulfide bond 


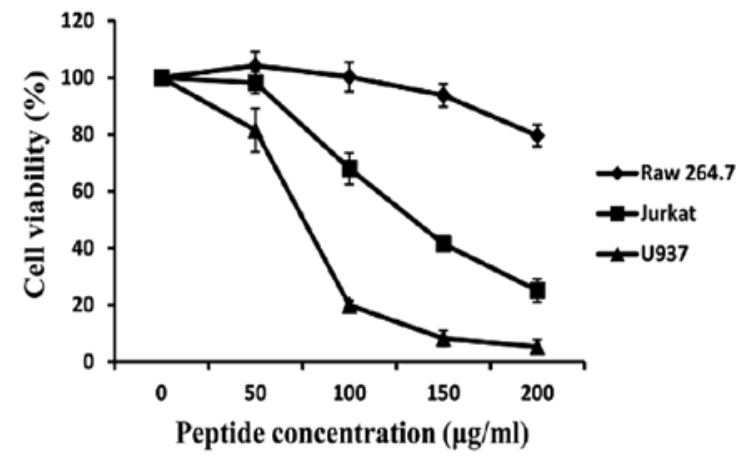

Figure 1. Cell viability of the human leukemic cell lines after HaA4 treatment. Cells were treated with different concentrations $(0,50,100,150$ and $200 \mu \mathrm{g} / \mathrm{ml}$ ) of $\mathrm{HaA} 4$ for $24 \mathrm{~h}$ and cell viability was measured by the MTS assay. Error bars represent the standard deviation derived from three independent experiments.

such as magainin 2 and melittin analogues showed stronger antimicrobial activity than the monomeric forms $(18,19)$. Moreover, halocidin dimer congeners derived from halocidin, a dimeric $\alpha$-helical structure peptide that was purified from the tunicate Halocynthia aurantium showed more potent antibacterial activity than the its monomer forms (20). Therefore, dimerization of the AMPs is suggested to potentiate their biological activity in an undefined way.

HaA4 markedly decreases cell viability of leukemia cell lines. Recently, we showed that synthetic HaA4 exerts antibacterial effect without hemolytic activities (17). We attempted to determine the effect of the synthetic peptide $\mathrm{HaA} 4$ on cell growth and survival of human leukemia cells (Jurkat and U937) in this study. Cancer cells were treated with various concentrations $(50,100,150$ and $200 \mu \mathrm{g} / \mathrm{ml})$ of $\mathrm{HaA} 4$ for $24 \mathrm{~h}$ and the cell viability was measured by MTS assay. As shown in Fig. 1, HaA4 decreased the viability of the leukemia cells in a dose-dependent manner. In particular, viability of the cells precipitated by $>70 \%$ at $200 \mu \mathrm{g} / \mathrm{ml}$ of $\mathrm{HaA} 4$, while $>70 \%$ of Raw 264.7 cells remained viable. Therefore, our results suggest that HaA4 should exert a potent anticancer activity against human leukemia cells.

Effect of HaA4 on the integrity of cancer cell membrane. We attempted to characterize the effects of $\mathrm{HaA} 4$ on the integrity of cancer cell membranes by detecting the LDH activity. As shown in Fig. 2, the amount of LDH release increased in a dose-dependent manner in both cancer cell types and the percentage of cytotoxicity appeared to reach plateau with the elevation of the peptide concentration. Although level of LDH release from both was similar, LDH release from U937 was a little higher than that from Jurkat. Maximal cytotoxicity at $200 \mu \mathrm{g} / \mathrm{ml} \mathrm{HaA} 4$ was 43.3 and $55.7 \%$ for Jurkat and U937 cells, respectively. However, HaA4 showed cytotoxic activity against Raw 264.7 cells and the LDH release was similar to Jurkat cells. Base on the results, we surmised that lytic activity of HaA4 is influenced by the presence of serum. Although HaA4 had no hemolytic activity in our previous report (17), cell selectivity of HaA4 including serum stability needs to be examined further. Finally, when compared to the results from the MTS assay, the reduction in cell viability

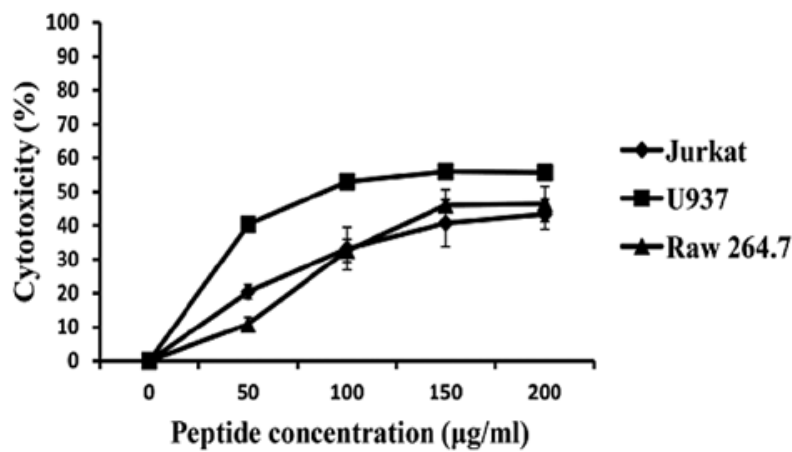

Figure 2. HaA4 causes cell membrane disruption. Cells were incubated with $\mathrm{HaA} 4$ for $24 \mathrm{~h}$ and treated samples assessed by LDH release assay. The results are expressed as the means \pm SD from three individual measurements.

was $30-40 \%$ higher than expected from cytotoxicity. The observed discrepancy suggested that additional factors including apoptosis and growth inhibition as well as necrosis could play a critical role in the viability reduction by $\mathrm{HaA} 4$.

HaA4 induces apoptosis and necrosis in leukemia cells. In order to further characterize mechanism of the viability reduction, we assessed the involvement of apoptosis. Apoptosis (programmed cell death) is a pivotal physiological process that is required for the normal development and maintenance of tissue homeostasis in multicellular organisms (21). During apoptosis, certain morphological characteristics are involved, such as membrane blebbing, phosphatidyl inositol exposure, nuclear and cytoplasmic shrinkages, chromatic condensation and DNA fragmentation (22). Apoptosis was examined by Annexin V/PI staining of the HaA4-treated leukemic cells. Annexin V binding to the HaA4-treated leukemia cells was gradually increased as the peptide concentration elevated. Annexin V-positive cell population reached maximum at $150 \mu \mathrm{g} / \mathrm{ml} \mathrm{HaA} 4$, while Annexin V/PI-positive at $200 \mu \mathrm{g} /$ ml HaA4 (Fig. 3). These results indicated that HaA4 should induce both apoptosis and necrosis depending on the concentration of HaA4. Necrosis appeared prevailing over apoptosis at higher concentration of HaA4.

Previously it has been reported that piscidin-1, a cationic peptide isolated from the mast cells of hybrid striped bass (23), also causes apoptosis and necrosis at a low concentration and necrotic effect at a high concentration for a short period in HT1080 cells (24). Piscidin-1 has a net charge of +3 and $\mathrm{HaA} 4$ has a net charge of +2 at $\mathrm{pH} 7.0$, which might function in the anticancer activity. Net charge of a peptide is an important parameter for antitumor activity (25). Thus, it is supposed that the positively charged cationic peptide could interact with anionic cancer cell membrane electrostatically and damage the membrane integrity.

Acridine orangelethidium bromide staining. To verify Annexin V/PI assay results, HaA4-treated Jurkat cells were stained with acridine orange/ethidium bromide. After HaA4 treatment for $24 \mathrm{~h}$, majority of cells exhibited green fluorescence in control, while diffused or orange-colored nuclei were increased in $\mathrm{HaA} 4$-treated cells with increase of $\mathrm{HaA} 4$ concen- 


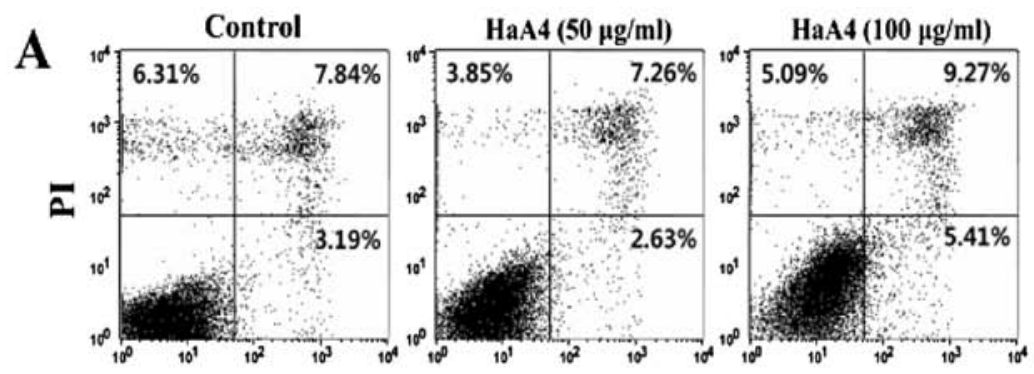

Annexin V FITC

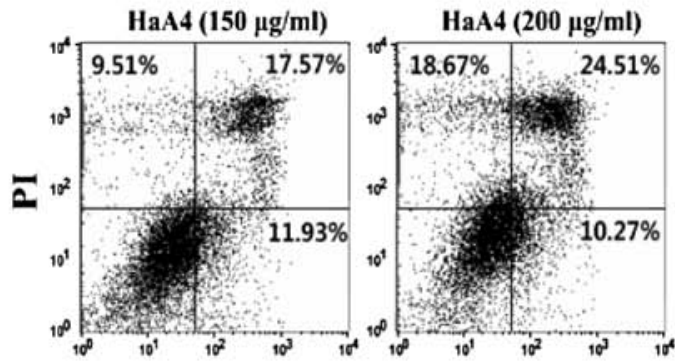

Annexin V FITC

Annexin V FITC
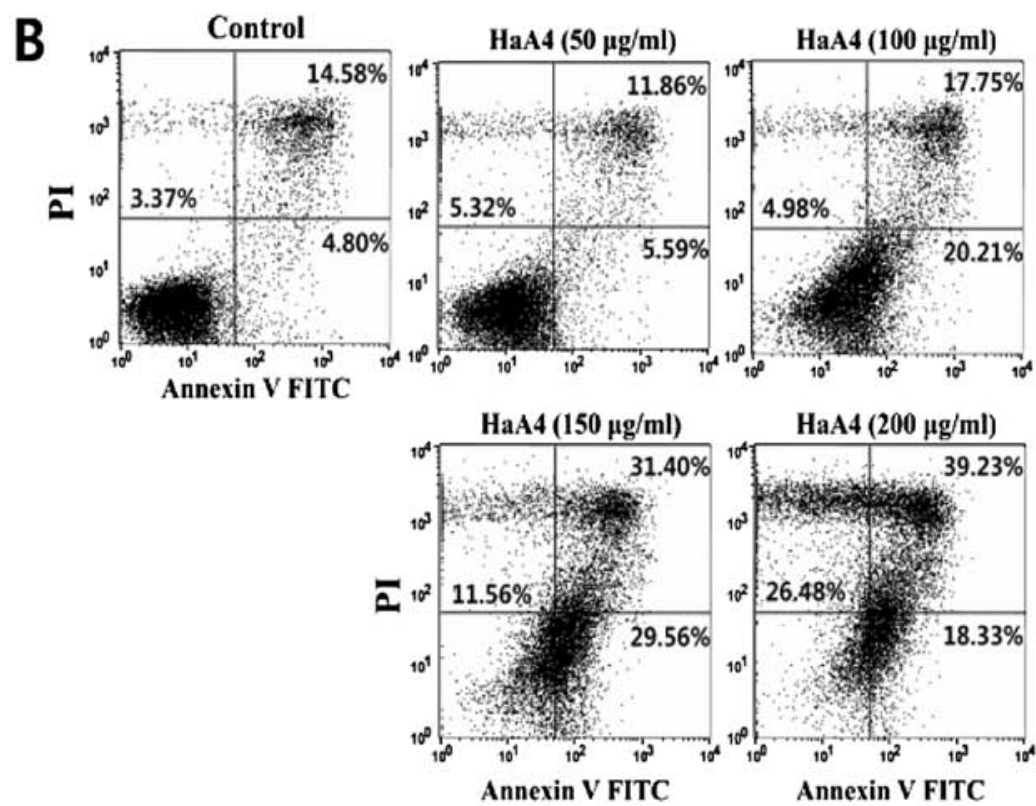

Figure 3. HaA4 induces apoptotic and necrotic cell death of the human leukemic cells. Cancer cells were treated with various concentration of HaA4, stained with FITC-conjugated Annexin V/propidium iodide and subjected to flow cytometry. The lower left part represents viable cells and the lower right part represents early apoptotic cells and the upper left part represents necrotic cells and the upper right part represents secondary necrotic and late apoptotic cells. (A) Jurkat cells. (B) U937 cells.

tration. The cells treated with $150 \mu \mathrm{g} / \mathrm{ml} \mathrm{HaA} 4$ developed orange and orange-red fluorescence, indicating membrane disruption (Fig. 4). U937 cells presented similar results (data not shown). These results support that $\mathrm{HaA} 4$ could induce both apoptosis and necrosis at high concentrations.

HaA4-induced DNA fragmentation. In order to further determine whether apoptosis is involved in the viability reduction of the leukemia cells, we performed TUNEL assay and agarose gel electrophoresis for chromosomal DNA after treating these cells with $200 \mu \mathrm{g} / \mathrm{ml}$ of HaA4 for $24 \mathrm{~h}$. As shown in Fig. 5A, the number of TUNEL-positive apoptotic cells was significantly increased in Jurkat and U937 cells treated with HaA4 when compared with the untreated cells. In agreement with the results, the chromosomal DNA of Jurkat and U937 cells was fragmented in nucleosomal ladder by HaA4 (Fig. 5B). Based on these results, we assured that such pro-apoptotic effects of HaA4 should contribute to the viability reduction of the leukemia cells.

HaA4 induces apoptosis in the leukemia cells via a caspasedependent pathway. Since apoptosis can proceed via either caspase-dependent or -independent signaling pathways $(26,27)$, the involvement of caspases in HaA4-induced leukemia cell apoptosis was assessed. As shown in Fig. 6, a marked increase in the cleavage of caspase-7, -9 and PARP was observed. Subsequently, the potential role of apoptosis inducing factor (AIF), a caspase-independent apoptosis regu- 

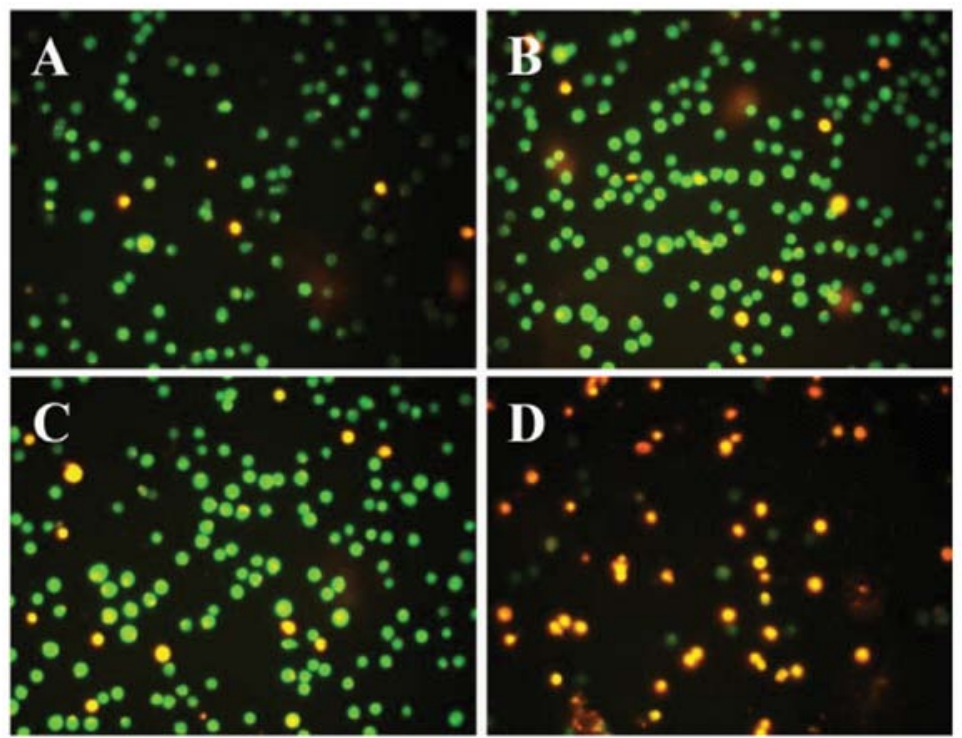

Figure 4. Jurkat cells were stained with acridine orange/ethidium bromide after incubation with HaA4. Cells were observed under fluorescence microscope (x400). Viable cells show green fluorescence. Necrotic and apoptotic cells show orange and yellow fluorescence. (A) No treatment control. (B) Cells were treated with $50 \mu \mathrm{g} / \mathrm{ml} \mathrm{HaA} 4$. (C) Cells were treated with $100 \mu \mathrm{g} / \mathrm{ml} \mathrm{HaA} 4$. (D) Cells were treated with $150 \mu \mathrm{g} / \mathrm{ml} \mathrm{HaA4}$.
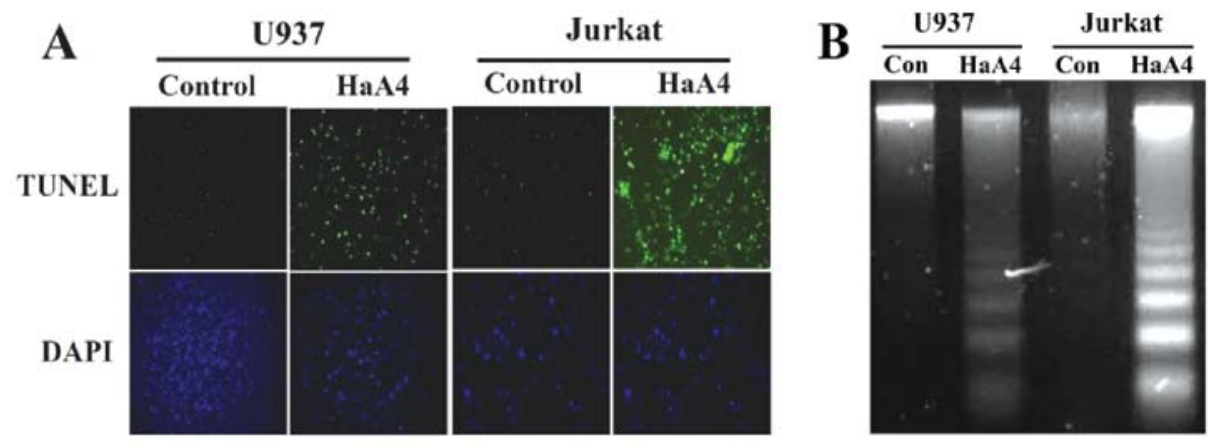

Figure 5. TUNEL assay (A) and DNA fragmentation analysis (B) were carried out to demonstrate apoptotic cancer cells following treatment with $200 \mu \mathrm{g} / \mathrm{ml}$ of $\mathrm{HaA} 4$ for $24 \mathrm{~h}$. The fluorescence microscopic images were taken at $\mathrm{x} 400$ magnification.

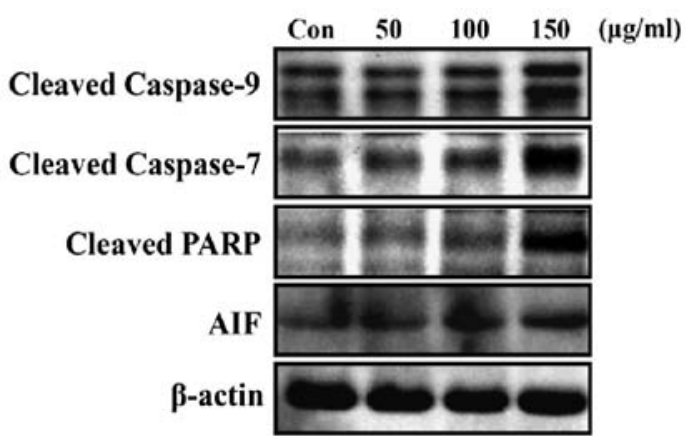

Figure 6. HaA4-induced apoptosis is associated with a caspase-dependent pathway. Jurkat cells were exposed to medium (con) or HaA4 (50, 100 and $150 \mu \mathrm{g} / \mathrm{ml}$ ) for $24 \mathrm{~h}$. Caspase-7 and -9 were activated and PARP was cleaved by HaA4 in Jurkat cells.

lator on HaA4-induced apoptosis was investigated. However, we could not observe converted mature form of AIF (Fig. 6). These results suggest that $\mathrm{HaA} 4$-mediated leukemia cell apoptosis might be associated with the activation of caspase.

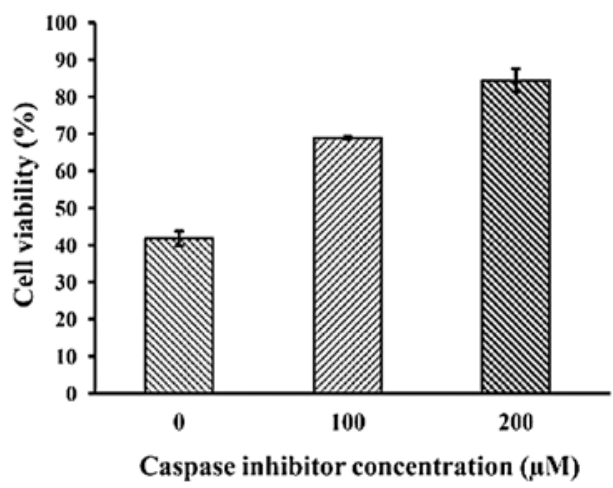

Figure 7. Jurkat cells were treated with Z-VAD-FMK $(0,100$ and $200 \mu \mathrm{M})$ in $\mathrm{HaA} 4(150 \mu \mathrm{g} / \mathrm{ml})$. Cell viability recovered depending on the concentration of Z-VAD-FMK. The bars represent the mean \pm SEM of 3 independent experiments performed in triplicate.

Moreover, the decreased cell viability by HaA4 treatment in the MTS assay recovered in the presence of Z-VAD-FMK, a pan-caspase inhibitor (Fig. 7), demonstrating that HaA4- 
induced leukemia cell apoptosis is dependent on the activation of the caspase family proteins.

Most antibacterial and anticancer peptides employ cell membrane disruption by lytic activity, or some peptides employ apoptosis in cancer cells through mitochondrial damage. It is believed that the mode of action originates from electrostatic interaction between cationic peptides and anionic cell wall components of bacterial and cancer cells. To date, there are four possible different models (toroidal, carpet, barrel-stave and aggregate channel) of AMP action mechanisms for membrane permeabilization (28). In previous studies, $\alpha$-helical peptides were shown to need more than 20 amino acid residues to span the entire thickness of the eukaryotic cell membranes for the barrel-stave mechanism $(29,30)$. Thus, the relatively small size of HaA4 along with aurein 1.2 (31) and citropin 1.1 (32), isolated from frogs suggest that these AMPs mediate their membranolytic effect through the carpet mechanism (33). In addition, it has been reported that bovine lactoferricin binds to the cell membrane and causes cell membrane disruption followed by entry of the peptide to the cytoplasm of Jurkat T-leukemia cells and damage to mitochondrial membrane (34). Based on the results of our previous study (17), it was postulated that $\mathrm{HaA} 4$ acts on anticancer activity similar to bovine lactoferricin, although the exact mechanism of $\mathrm{HaA} 4$ has to be elucidated.

In this report, we have shown that $\mathrm{HaA} 4$ is a good candidate for a new anticancer therapeutic agent as described above. As a consequence, we could identify necrotic effects of HaA4 via LDH activity detection (Fig. 2) and Annexin V and PI staining (Fig. 3) and we also observed that HaA4 indicates apoptotic effects. Additionally, apoptosis of the leukemic cells by $\mathrm{HaA} 4$ was dependent on the activation of caspase (Figs. 6 and 7), a regulator of a caspase-dependent pathway. Overall, our present study revealed that $\mathrm{HaA} 4$ should retain anticancer activity against human leukemia cells (Jurkat and U937) and the activity might ascribe to necrosis and apoptosis of the leukemia cells.

\section{Acknowledgements}

This study was supported by a grant from the Next-Generation BioGreen 21 Program (no. PJ008158) and partially supported by a grant (no. PJ008706) from the Agenda Program, Rural Development Administration, Republic of Korea.

\section{References}

1. Lehrer RI, Lichtenstein AK and Ganz T: Defensins: antimicrobial and cytotoxic peptides of mammalian cells. Annu Rev Immunol 11: 105-128, 1993.

2. Zasloff M: Antimicrobial peptides of multicellular organisms. Nature 415: 389-395, 2002.

3. Koczulla AR and Bals R: Antimicrobial peptides: current status and therapeutic potentials. Drugs 63: 389-406, 2003.

4. Bulet P, Hetru C, Dimarcq JL and Hoffmann D: Antimicrobial peptides in insects; structure and function. Dev Comp Immunol 23: 329-344, 1999.

5. Bulet $\mathrm{P}$ and Stocklin R: Insect antimicrobial peptides: structures, properties and gene regulation. Protein Pept Lett 12: 3-11, 2005.

6. Matsuyama K and Natori S: Purification of 3 antibacterial proteins from the culture medium of NIH-Sape-4, an embryonic cell line of Sarcophaga peregrina. J Biol Chem 263: 17112-17116, 1988.
7. Bulet P, Cociancich S, Reuland M, Sauber F, Bischoff R, Hegy G, Van Dorsselaer A, Hetru C and Hoffmann JA: A novel insect defensin mediates the inducible antibacterial activity in larvae of the dragonfly Aeschna cyanea (Paleoptera, Odonata). Eur J Biochem 209: 977-984, 1992.

8. Baker MA, Maloy WL, Zasloff M and Jacob LS: Anticancer efficacy of Magainin2 and analogue peptides. Cancer Res 53: 3052-3057, 1993.

9. Moore AJ, Devine DA and Bibby MC: Preliminary experimental anticancer activity of cecropins. Pept Res 7: 265-269, 1994.

10. Soballe PW, Maloy WL, Myrga ML, Jacob LS and Herlyn M: Experimental local therapy of human melanoma with lytic magainin peptides. Int J Cancer 60: 280-284, 1995.

11. Xiao YC, Huang YD, Xu PL, Zhou ZQ and Li XK: Pro-apoptotic effect of cecropin AD on nasopharyngeal carcinoma cells. Chin Med J (Engl) 119: 1042-1046, 2006.

12. Iwasaki T, Ishibashi J, Tanaka H, Sato M, Asaoka A, Taylor D and Yamakawa M: Selective cancer cell cytotoxicity of enantiomeric 9-mer peptides derived from beetle defensins depends on negatively charged phosphatidylserine on the cell surface. Peptides 30: 660-668, 2009.

13. Hwang JS, Lee J, Kim YJ, Bang HS, Yun EY, Kim SR, Suh HJ, Kang BR, Nam SH, Jeon JP, Kim I and Lee DG: Isolation and characterization of a defensin-like peptide (Coprisin) from the dung beetle, Copris tripartitus. Int J Pept doi: 10.1155/2009/136284, 2009.

14. Kang JK, Hwang JS, Nam HJ, Ahn KJ, Seok H, Kim SK, Yun EY, Pothoulakis C, Lamont JT and Kim H: The insect peptide coprisin prevents Clostridium difficile-mediated acute inflammation and mucosal damage through selective antimicrobial activity. Antimicrob Agents Chemother 55: 4850-4857, 2011.

15. Kim IW, Kim SJ, Kwon YN, Yun EY, Ahn MY, Kang DC and Hwang JS: Effects of the synthetic coprisin analog peptide, CopA 3 in pathogenic microorganisms and mammalian cancer cells. J Microbiol Biotechnol 22: 156-158, 2012.

16. Kang BR, Kim H, Nam SH, Yun EY, Kim SR, Ahn MY, Chang JS and Hwang JS: CopA3 peptide from Copris tripartitus induces apoptosis in human leukemia cells via a caspase-independent pathway. BMB Rep 45: 85-90, 2012.

17. Kim IW, Lee JH, Park HY, Kwon YN, Yun EY, Nam SH, Kim SR, Ahn MY and Hwang JS: Characterization and cDNA cloning of a defensin-like peptide, harmoniasin, from Harmonia axyridis. J Microbiol Biotechnol 22: 1588-1590, 2012.

18. Hara T, Kodama H, Kondo M, Wakamatsu K, Takeda A, Tachi T and Matsuzaki K: Effects of peptide dimerization on pore formation: antiparallel disulfide-dimerized magainin 2 analogue Biopolymers 58: 437-446, 2001.

19. Takei J,Remenyi A,Clarke AR and Dempsey CE: Self-association of disulfide-dimerized melittin analogues. Biochemistry 37: 5699-5708, 1998.

20. Jang WS, Kim CH, Kim KN, Park SY, Lee JH, Son SM and Lee IH: Biological activities of synthetic analogs of halocidin, an antimicrobial peptide from the tunicate Halocynthia aurantium. Antimicrob Agents Chemother 47: 2481-2486, 2003.

21. Wyllie AH: Apoptosis: An overview. Br Med Bull 53: 451-465, 1997.

22. Raff M: Cell suicide for beginners. Nature 396: 119-122, 1998.

23. Silphaduang U and Noga EJ: Peptide antibiotics in mast cells of fish. Nature 414: 268-269, 2001.

24. Lin HJ, Huang TC, Muthusamy S, Lee JF, Duann YF and Lin CH: Piscidin-1, an antimicrobial peptide from fish (hybrid striped bass Morone saxatilis x M. chrysops), induces apoptotic and necrotic activity in HT1080 cells. Zoolog Sci 29: 327-332, 2012.

25. Diao Y, Han W, Zhao H, Zhu S, Liu X, Feng X, Gu J, Yao C, Liu S, Sun C and Pan F: Designed synthetic analogs of the $\alpha$-helical peptide temporin-La with improved antitumor efficacies via charge modification and incorporation of the integrin $\alpha v \beta 3$ homing domain. J Pept Sci 18: 476-486, 2012.

26. Zeuner A, Eramo A, Testa U, Felli N, Pelosi E, Mariani G, Srinivasula SM, Alnemri ES, Condorelli G, Peschle C and De Maria R: Control of erythroid cell production via caspasemediated cleavage of transcription factor SCL/Tal-1. Cell Death Differ 10: 905-913, 2003.

27. Kitanaka C, Kato K and Tanaka Y: Ras protein expression and autophagic tumor cell death in neuroblastoma. Am J Surg Pathol 31: 153-155, 2007.

28. Li Y, Xiang Q, Zhang Q, Huang Y and Su Z: Overview on the recent study of antimicrobial peptides: origins, functions, relative mechanisms and application. Peptides 37: 207-215, 2012. 
29. Shai YC: Molecular recognition between membrane-spanning peptides. Trends Biochem Sci 20: 460-464, 1995.

30. Epand RM, Shai YC, Segrest JP and Anantharamaiah GM: Mechanisms for the modulation of membrane bilayer properties by amphipathic helical peptides. Biopolymers 37: 319-338, 1995.

31. Rozek T, Wegener KL, Bowie JH, Olver IN, Carver JA, Wallace JC and Tyler MJ: The antibiotic and anticancer active aurein peptides from the Australian Bell Frogs Litoria aurea and Litoria raniformis the solution structure of aurein 1.2. Eur J Biochem 2671: 5330-5341, 2000.

32. Doyle J, Brinkworth CS, Wegener KL, Carver JA, Llewellyn LE, Olver IN, Bowie JH, Wabnitz PA and Tyler MJ: nNOS inhibition, antimicrobial and anticancer activity of the amphibian skin peptide, citropin 1.1 and synthetic modifications. The solution structure of a modified citropin 1.1. Eur J Biochem 270: 1141-1153, 2003.
33. Hoskin DW and Ramamoorthy A: Studies on anticancer activities of antimicrobial peptides. Biochim Biophys Acta 1778: 357-375, 2008.

34. Mader JS, Richardson A, Salsman J, Top D, de Antueno R, Duncan R and Hoskin DW: Bovine lactoferricin causes apoptosis in Jurkat T-leukemia cells by sequential permeabilization of the cell membrane and targeting of mitochondria. Exp Cell Res 313: 2634-2650, 2007. 